\title{
FACTORS INFLUENCING THE RISE OF HOUSE PRICE IN KLANG
}

\section{VALLEY}

\author{
Cindy Liew', Nuzul Azam Haron² \\ ${ }^{1}$ Student, ${ }^{2}$ Lecturer, Department of Civil Engineering, Universiti Putra Malaysia, 43400, Serdang, Selangor, Malaysia \\ cindyliewcindyliew@gmail.com,nuzul@upm.edu.my
}

\begin{abstract}
There is an increase of house price radically in Klang Valley that affect to Malaysian house buyer. House price is the value to be paid for the dealing of buying a residential property. House price rises continuously respecting few factors and had impacting house buyer in decision to buy their house. This study becomes necessary since there is less research that gives information in the factors influencing the rise of house price. The factors are found out through detailed literature reviews and information from pilot study. Pilot study is conducted through interviewing representative from National House Buyer Association, pioneer in solving house related problem, to provide legal suggestion and etc. The data is collected via questionnaire survey form distributed to respondents in sample area. The sample area is Klang Valley region, 10 municipal districts including Kuala Lumpur, the Capital City. In result and analysis stages, the factors had to be refined by analyzing the data using statistical tests. Every single factors are calculated its average index respect to few level of influence under respondents' opinion. The index will then treated as influencing level of the factors. Based on the study, fluctuation in housing market, increasing in construction cost, population growth and increasing demand are factors which give major influence to rise of house price. The study also identified housing criteria to be considered during setup of house selling price and also preference among house buyer nowadays. This study also identified cost contributors in construction being foresees as control measure concerned in respect to respondents point of view.
\end{abstract}

Keywords: House price, affordable, and construction cost

\section{INTRODUCTION}

House price definition may differ by different personnel such as developer, contractor, dealer, and buyer (Lee, 2009). According to Michele (2012), house price is a value for a residential property which get the perfect balance between attracting solid offers and ultimately receiving top money. While Lee (2009) defined house price as value to be paid for the transaction of buying a residential property which more to buyer's perspective.

House is shelter to support a household living and a basic need for all humanity. Owning a house is a key goal of life which everybody pursuing with. House price is main consideration to make decision for owning a house. In the mean time, buyers also consider the location, accessibility, facilities, and others (Ameera et al., 2012). House price can rise once updated with public infrastructure like highway, and public transport nearby, while it will keeps rising as property owner or broker bid up of price according to market demand.

The Klang Valley housing and property are in unhealthy growth against Mass Rapid Transit project which had planned to interlink the Capital city and its sub-cities (CBRE, 2011). For sure, developers scramble for project near to designated station and claim that as prime area (Mohammad et al., 2010). Also, house price is rose exponentially with inflation rate, crude oil price and other constituents. High value of house price had actually, make buyers delayed to own a house, or forced them to consider other than their preference, or suffering with high housing loan. Klang Valley house price had a dramatic up raise in the duration of 2009-2011, a moderate rise of $17 \%$ and another $14 \%$ rise of transaction volume (Goh, 2012).

Vibrant house price is directly influencing the level of homeownership in Klang Valley. To avoid more and more Malaysian losing opportunity to own an affordable house, it is important to foresee the issue in deep with particular research. Also, this could highlight the key to help policy maker for providing solution on controlling the rising rate of house price and strengthening or stabilizing the market with healthy demand-supply chain. Therefore, this paper aims to investigate the factors influencing the rise of house price in Klang Valley, a compound area associating rapid economic and social growth consisting Kuala Lumpur and its sub-cities.

Klang Valley is conducting highly developing action in economy and living quality. Increase in population, migrant, and immigrant had pressurizing housing demand. House demand is still remains high even through there are continuously mark up of house price. This had clearly reflecting fluctuation between the demand and supply. 
Klang Valley is making up of $49 \%$ total housing transaction in Malaysia with amount RM61.38billion with $17 \%$ increment during the year 2009-2011. However, there are 14\% traced increment in house transaction volumes during the same period (Goh, 2012). Sharp rise in house price with unsupportive economy fundamental and social backbone should lead to bubble in housing market. Burst of the bubble would indicate the housing market losing persistent rise in house price over length period and sudden drop in house price. This had made house buyer loss their wealth management in dealing with high interest rate, low income increment, and price inflation of living goods. Same situation had happened in South Korea, Taiwan, and Hong Kong beating the sector development especially mortgage lender, material trader and construction activity.

The limitation of previous studies are more discussing house price on affordability and housing bubble as had been done by Mohd et al.(2012) and Zainal (2010). Different in household income growth and affordable range causing individuals or groups hold different point of view on evaluating influence level and impact of rising house price toward their locality (Chen, 2000).

Thus, discussion on judging the relationship between house price to income and affordability are seem certainly correlated but there are other factors that implied into housing markets which play a pivotal role in country economy. There are others factor that had direct or indirect influencing rise of house price. By knowing the factors, effective measure can be managed to control house price at reasonable range.

Hence, this research is entitled to run a public survey in Klang Valley region on highlighting important factors that had causing increment of house price. Influencing level of each factor is to be calculated. The factor and its influencing level can be highlighted in order to come out with solution for providing affordable house price in Klang Valley, also act as guidance and reference for future.

\subsection{Research Objective}

House price is nothing more a burden for house owner. It is also an obstacle for peoples who consider buying a house. It is good to know the current situation and investigate the factor that contributing to house price growth.

This study is carried out to study and identify main factors which influence the rise of house price in Klang Valley and to determine influencing level of the factors which influence the rise of house price in Klang Valley.

\section{LITERATURE REVIEW}

Chen (2000) and Lew et al. (2003) stated Malaysia need a total of $8,850,554$ houses, including 4,964,560 units of new housing to provide accommodation for about $20 \%$ out of total population in between the years 1995 to 2020 . Unfortunately, only $1,382,917$ units were constructed under the 6th (19911995) and 7th (1996-2000) Malaysia Plan. Another 3,581,643 units have to be built within the next twenty years. That is, on average $1,790,820$ units to be built for every ten years and the achievement is only 844,043 units in between 2001-2005 and the housing demand is on average 709,400 units during 9th Malaysia Plan (2006-2010). It is clear that unless a extreme change of policy pertaining to population growth is adopted, or some new solution for this increase housing demand is implemented, the housing problems is expected to continue for years to come.

\subsection{Housing Property Trend in Klang Valley}

Klang Valley is a vibrant and huge market by making up of about half $(49 \%)$ of total housing transaction value in Malaysia worth RM61.38 billion with high rate of lowerpriced unit being transacted (Terence, 2012). Semi detached house in Klang Valley had recorded the highest price rise of $18.8 \%$ due to low supply rate while high demand in the market. In Kuala Lumpur, house price rose $12.2 \%$ with average RM6700 per square meter during 2010 to 2011 when the housing market slightly heated up (Talhar \& Wong, 2012). Klang Valley had make up with more than $40 \%$ housing stock throughout whole Malaysia. Hence at any instant, it would be the largest both influencing and influenced group in housing market. So, healthier the housing supply and demand chain and affordable house price are among the effort to overcome price fluctuate in housing market. There is an inversing phenomenon that today's buyers are intended to own high rise, condominium or flats, which more compatible with their affordable range.

\subsection{The Demand and Supply}

Rising of house price is toughly reflecting fluctuation between demand and supply trend. The supply growth of residential property in Klang Valley had drop to $1.5 \%$ in 2011 (Lee, 2009). This shows poorest performer as compare back to ten years time. This slowdown reflects an unbalance in housing market where the supply is always lagging behind population growth and the need of housing, hence house price would continue to rise. Furthermore, house price index for the year 2011 in Klang Valley had doubled as compared back to 2001. Back to mid 1990's, presented demand to supply ratio for residential property was high. There is always a gap between housing demand-supply with significant widening effect (John, 1999). According to statistical date from JPPH (2012), the National House Price Index rose $6.1 \%$ from $8.9 \%$ growth last year during first quarter 2012 as compared to the same period 2011 with average house price RM 219,000. District like Kuala Lumpur, Ampang, Klang are recorded as group of biggest increment, $46 \%, 97 \%$ and $65 \%$ respectively. 
In constraint of housing supply, the responsiveness of expanding housing stock or supply may decreases, since in common context, the price rates is being adjusted high for more wages rather than expanding the industry to build more house for balancing the demand rates (Dan, 2010). These situation often occurred to the countries with higher population rates, and these becomes practical reason for broker and housing agent to create market volatility and price fluctuation (Johansson, 2010). Mamta (2012) studied the trend in New York City; revealed rising house price is strongly connected with job growth, migrant and immigrant growth, and supply and demand rates. House price is far more complicated which due with dynamic market, and critical demand and supply ratio fluctuation. Demand on house depends on flexible buying ability (Stephen, 2010). Key area like Klang Valley had accepting strong urban migration volume which also subject to population growth and housing supply pressure (Thean, 2012). Housing supply tends to be less responsive to urban migration and remains still uncertain with high climb of demand. This is determinant factor of house prices growth in most countries since the inflow strengthening tough reason of supplying developers, owned house reseller, buy and sell agent rise the house price along with inexhaustible demand (Dan, 2010).

\subsection{The Cost of Construction}

In overall approach, Haron et al. (2005) expressed construction cost must take into account all time dependent and quality dependent component which includes, all cost on labour, materials, investment and general expenses, transportation, and overhead per control floor area measure. Housing investment had contributing important effects on house price which includes the profit changes, worker employments, and housing demands (OECD, 2005).

\subsubsection{Material Cost}

Construction cost is important segment in construction project management which driving project success. It can be divided in project resource planning, cost budgeting, cost control and cost estimating (Ramli, 2003) in price of material, labour, technology, machinery, land (area), and transportation. Material price is undeniably the highest financial load in any construction industry (Ibrahim et al., 2012; Thanoon et al., 2003). Associated with rise of material production and processing price, contractor nothing more should afford the rise of material price and forced them raising the selling price of their finished unit.

\subsubsection{Land Price}

Real Estate and Housing Developers' Association (REHDA) expressed that My First Home Scheme or Perumahan Rakyat 1 Malaysia (PR1MA) to develop housing unit at average price between RM100,000 and RM220,000 in Klang Valley, Kuala Lumpur and neighborhood city would be challenging
(Edmund, 2012). Availability of land for housing development, elasticity of land zoning regulation, restriction by housing policy, under satisfaction administration procedure are toughly impact availability of developable land for housing property (OECD, 2005). Land availability in Klang Valley is a crucial issue. Rise of land price challenges seeking of suitable and strategic land for building new housing property. Development land in prime urban and suburban locations of Klang Valley will always be in high demand with a reference price of RM1,525 per square feet and may subject to gradual up-climb as developers have to adopt a strategic, long-term view in expanding their land banks (Thean, 2012). According to local authorities, they had been receiving enquiries from both the developers showing interest seeking for developable land around Klang Valley (Tan, 2005). High profile, good side lands in this area are able to be developed towards high class, elegance and leisure housing property which had significant rise in demand recently.

\subsubsection{Labour}

Malaysia construction sector is facing shortage of skilled labour force and foreign labour source in market. This is due to large variety of demand against supply and attitude of Malaysia's young generation nowadays show that they are not interesting in construction work (Hamzah et al., 2012). Semiskilled and skilled foreign workers with local languages spoken are easier being absorbed to work with other employer, who providing higher pay (Aziz, 2001; Bakar, 2002). Malaysian developers and contractors need foreign worker for plenty of general construction working with even less pay than local workers (Kassim, 2005). Hence, wages and benefits had been improved for winning labour force during shortage, coincident with high rate of development (Sambasivan \& Yau, 2007 ; Narayanan \& Lai, 2005). However, foreign labours are employed under temporary work passes which entitled to short renewable period and with condition to re-entry.

\subsection{Conventional and Industrialized Building System}

To cope with 600,000-800,000 unit affordable, low and medium cost housing, Malaysia construction sector need a system that can produce frequent tasks, low cost constructing methods and less man power involvement which can absorb most capital and overhead cost using conventional construction method (Lew et al., 2003).

While the crisis of housing grows more heightened, Malaysia is under pressure to meet its own housing needs by increasing appliance of advanced technology. The conventional construction method is not able to meet the demand, due to the slow rate of construction and higher cost (Agus, 1997).

Hence, the alternative solution must be industrialized building system. The Government and construction experts had started on reviewing the implement-ability of construction methods 
using industrialized building system against the current methods of high dependency on foreign work force (Ismail, 2001). Razali et al. (2006) mentioned that dependency on labour force is strictly poor measure as both labour cost and structural cost are found not compatible varies with labour productivity. However, shifting to industrialized building system involved cost manner which most contractor may still maintain the conventional building system (Thanoon et al., 2003). However, the cost for implementation may compensate throughout the life cycle of the project (Lou \& Kamar, 2012). The main aims in industrialized building system are reducing time and cost into construction which in particular reducing on site working and labour demand. Badir et al. (1998) grouped industrialized building system into: cast in-situ formwork, prefabricated and composite system, three main categories. Modern, new invented construction technology and machinery consumed additional cost and particular skill into operation beside it reduces construction time (Ismail, 2001). Malaysia is presently taking a serious look at industrialized building system as an answer to the housing shortage problem (Ismail, 2001). In current stage, industrialized building system is seem difficult in implementation due to the lack of design standard, unavailability of training, shortage of new worker exposed to skill in practice, less active manufacturer, and limited market for product (Lou \& Kamar, 2012; Khalfan et al., 2008).

\subsection{Housing Quality and Appearance}

Salleh and Shiadri (2008) found that the neighborhood condition also an dominant factors affecting the levels of housing satisfaction in Malaysia housing sector during research in Penang and Terengganu. Oh (2000) expressed that space and house price in Malaysia is achieving high satisfaction, however size of kitchen and toilet, availability of public facilities are below satisfaction.

Table 1: Variables into housing quality as summarized description by few researchers

\begin{tabular}{|c|c|}
\hline Housing quality variables & Source \\
\hline $\begin{array}{l}\text { Design and Appearance } \\
\text { Management Practices } \\
\text { Surrounding social aspects }\end{array}$ & Francescato et al. (1987) \\
\hline $\begin{array}{l}\text { Dwelling unit } \\
\text { The management services } \\
\text { Neighbourhood and social area }\end{array}$ & $\begin{array}{l}\text { Varady and Carozza } \\
(2000)\end{array}$ \\
\hline $\begin{array}{l}\text { Basic facilities in house } \\
\text { Basic public facilities available nearby }\end{array}$ & $\begin{array}{l}\text { Nurizan and Hashim } \\
(2001)\end{array}$ \\
\hline $\begin{array}{l}\text { Quality of the dwelling unit } \\
\text { Quality of the close environment } \\
\text { Quality of the urban site }\end{array}$ & Oh (2000) \\
\hline $\begin{array}{l}\text { Dwelling unit features } \\
\text { Dwelling unit support services } \\
\text { Public facilities } \\
\text { Social environment } \\
\text { Neighborhood facilities }\end{array}$ & Mohammad et al. (2010) \\
\hline $\begin{array}{l}\text { Location characteristic } \\
\text { Housing area security (crime level) } \\
\text { Industrial development and work place location }\end{array}$ & Baker (1994) \\
\hline
\end{tabular}

\subsection{Government Policy}

\subsubsection{National Housing Policy}

Malaysian Government had imposed a low-cost housing quota upon private sector developers to provide affordable housing as the early year 1982. This policy imposed that project area exceeding 5 acres have to allocate at least $30 \%$ of houses as low cost units for balance socio-economy mix (Donald, 1989). Malaysian Government had announced a policy that first-time house buyer is eligible for $100 \%$ loan. It also announced a $50 \%$ reduction in stamp duty for houses costing RM350, 000 or less, and enforcing inventory of 65,000 unit new houses for market demand. Also, the new policy is applying taxation for controlling client who buy multiple units for rent and flip over for large money (Bawa \& Azriyati, 2010).

\subsubsection{Mortgage and Taxation}

The government had increased property gains tax from $5 \%$ to $10-15 \%$ for short-term transactions among first time home buyer for controlling flip over problem. This statement is seemed to ensure only serious buyer allowed for the program, and they are not to sell their units within construction period (Chong, 2012). 
The comfortable but long payback life loan had become a trend nowadays where banker has relaxed credit standards, are willing to lend up to $95 \%$ of the value of a property. This convenience had caused higher housing demand where richer persons are able to own multiple houses, and medium affordable group are willing to own a house with extra prolonging payback period, in case, this had purposely help rise the house price (Lee, 2009). Regulating mortgage rate, both decrease in loan to value and debt to income ratio, may subject to particular risks like upturn of house price which caused by boosted mortgage lending rate for house purchasing, as observing Korean situation (Hwang et al., 2010).

\subsubsection{Affordable Housing}

According to Hamzah et al. (2012), affordable housing in Malaysia context is described as constructed house unit with appropriate construction accordance, standard complied with code of practice created for low to medium as documented in CIS 1: 1998, and CIS 2: 1998, which low design specification on a area between 600-750 square feet and selling price range RM25, 000 to RM40, 000 for income range from RM750RM1,500. PR1MA, a more complete and greater coverage affordable housing program, had been implemented with provision of Budget 2012 backboned by 9th Malaysia Plan.

In contrast, the provision of affordable house must always associates with satisfaction housing quality like basic convenience, better feature, acceptance specification and size, good space layout. Also, green and sustainable practice would be a long term progression where the construction industry are on the path for achieving green agenda toward new housing concept and satisfaction (Bawa \& Azriyati, 2010).

\subsubsection{Transaction Fees}

Housing transaction may include some typical costs and fees, such as stamp duties, registration fees, real estate agency fees and other legal fees (Johansson, 2010; Dan, 2010).

Town planners and local councils should have comprehensive land use planning and give more importance to developing green and friendly cities, first class public transport system and less to the building of more shopping malls, hyper markets, and roads. In short, the government's priority should be to put the needs of the majority of Malaysians ahead that of banks, developers, speculators and rich foreigners.

\section{RESEARCH METHODOLOGY}

The general factors influencing the rise of house price in Klang Valley are found out through detailed literature reviews and information from pilot study. Pilot study is conducted through interviewing representative from National House Buyer Association. Detail information was collected from the pilot study and critical comment for the questionnaire. Questionnaire method was chosen as the appropriate approach for this study. The data was collected via questionnaire survey form distributed to respondents in sample area. The sample area is Klang Valley region which consist of 10 municipal councils. In result and analysis stages, the data for the factors influencing the rise of house price was to be refined by analyzing the data using Statistical Package for Social Science (SPSS). Every single factors are calculated its average index respect to few level of influence under respondents' opinion. The index will then treated as influencing level of the factors.

\section{RESULT AND DISCUSSION}

\subsection{Pilot Survey}

Pilot survey carries out with at least an interview with profession. The interview was held with Mr. Chang Kim Loong, Secretary-General of National House Buyer Associations. Mr. Chang Kim Loong consider that current house price in Klang Valley is too high beyond the wish of middle class and somehow not reasonable respecting to rising rate. House demand is high ranged from RM250000 to RM700000 from apartment to bungalow. Affordable house is strictly not enough for fulfilling the demand. Contractor does not take opportunity to increase house price but dealer most possibly take high commission fee in property market along with market fluctuation. Land price is highly influencing the rise of house price as it had obvious rise in construction cost. Housing quality stylish and satisfaction are minima influence when people buy a house. However, it is always affected by location. Different location in Klang Valley will have a different house price level even with the same house type. In objective point of view, PR1MA and My First House Scheme are not causing extra high demand. Lastly, refer to the society development plan by government, easy loan approval; affordable housing scheme, adjusted transaction fee and protection through government policy are increasing financial confidence among house buyer compared to early year.

\subsection{The demand and supply to house price}

Figure 1 showed $86 \%$ of respondents agreed urban migration had highly causing insufficient house instead of big demand, while $70 \%$ among them also agreed immigration of foreign immigrant and labour had highly influencing increase in house demand since they are in high volume crowding the Klang Valley region.

Urban migration is commonly happen due to certain reason. In urban area like Klang Valley, there is more job opportunity, education opportunity, and more entertainment facilities. People may migrant to Klang Valley region due to above reasons and this will totally influence the housing demand in Klang Valley. Those people may migrant from small town or other city in Malaysia to Klang Valley.

Foreign immigration may be very normal because Malaysia policy encourage foreign investment in Malaysia region. This scenario may contribute to much more foreigner to immigrate 
to Malaysia especially Klang Valley region which had many investment opportunity. Number of foreign immigrant may directly influence the increase of housing demand and thus may encourage the rise of house price.

Good job opportunities in Malaysia also encourage foreign labour to come and earn money. Many Malaysian do not like to join the labour work and this attitude contributes to the fact that we have to import foreign labour to work in Malaysia. Number of foreign labour increase may increase the housing demand and thus reflect to the rise of house price. In economics principle, when there is a demand increase, then the price will increase. Housing demand is a direct contributor to the rise of house price.

There are $44 \%$ respondents in opinion, gross domestic product highly increase house price so that it maintains stable and high condition. According to Malaysian Economic Outlook, real GDP grew 5.6\% in 2012, surpassed agreement forecasts of a little over $5.0 \%$ and the Treasury's 2013 Budget estimate of between $4.5-5.0 \%$. The 2012 growth was motivated by continuing high household demand, with extraordinary annual growth in both private expenditure and private and public investment outlays.

When inflation rate is high, it directly raises the cost of things and proportionally raises the house price. The inflation rate in
Malaysia was recorded at $1.7 \%$ in April of 2013. Inflation rate in Malaysia is stated by the Department of Statistics Malaysia. In Malaysia, statistic showed that most important categories in the consumer price index are food and non-alcoholic beverages and housing. Second important categories in the consumer price index are water, electricity, gas and other fuel. This mentions that most of the consumers spend their consumption in housing field. This is true in this research that $78 \%$ of the respondent opinion the inflation rate is one of the important influencing parameter on house demand, supply and house price and inflation rate had perceived highly pushed up periodical house price.

Concurrent with stable income, financial assistance, and protection through National Policy, housing demand is no longer reduced although of rising prices. At the mean time, house demand in current is not compatible with house supply in market supply of affordable house in market. Through this survey, research had found that housing supply somehow relate to responsiveness of investors or developers into house demand, at least $36 \%$ respondents had perceived this opinion. Also, there are $56 \%$ respondents in opinion house supply rate highly depends on project resources and quality management entitled. While $58 \%$ respondents stated involvement of foreign labour in construction not influence house selling price.

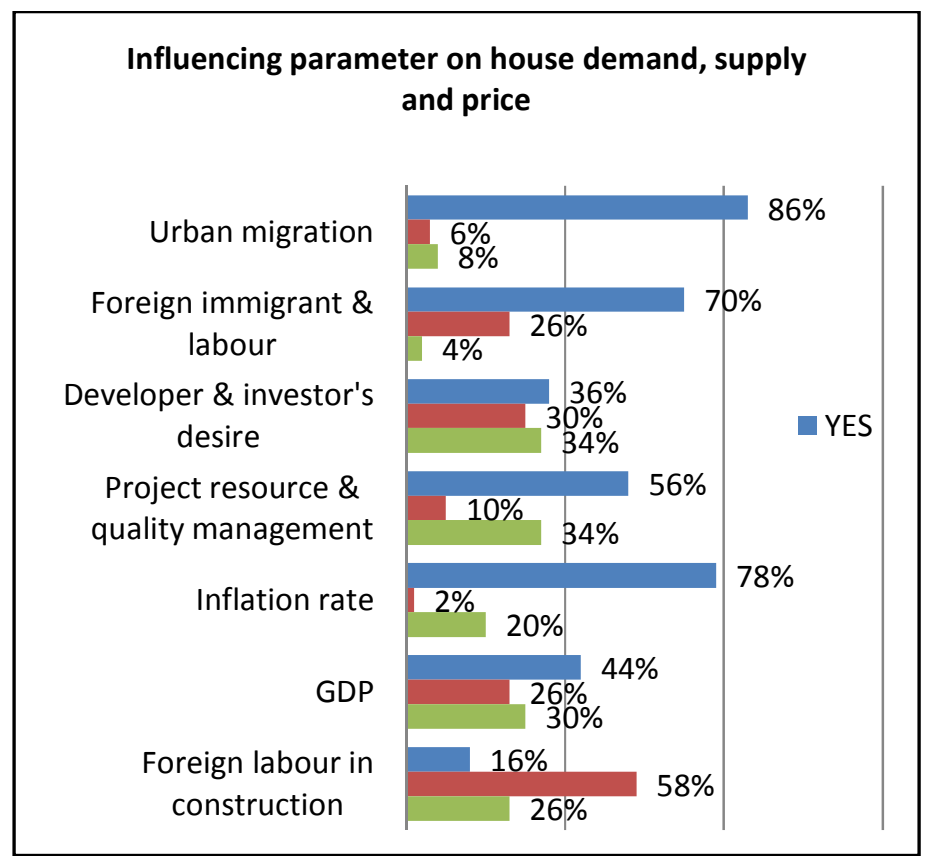

Figure 1: Percentage distribution by parameter on house demand, supply and price 
Table 2: Scale, average index and ranking of parameter regarding house demand, supply and price 'YES' represents by scale 3, 'Neither' by scale 2, and 'No' by scale 1 .

\begin{tabular}{|l|l|l|l|l|l|}
\hline $\begin{array}{l}\text { House Demand, Scale } \\
\text { Supply and Price parameter }\end{array}$ & 1 & 2 & 3 & $\begin{array}{l}\text { Average } \\
\text { Index }\end{array}$ & Rank \\
\hline Urban Migration - Demand & 3 & 4 & 43 & 2.8 & 1 \\
\hline Foreign Immigrant - Demand & 13 & 2 & 35 & 2.44 & 4 \\
\hline Developer's desire - Supply & 15 & 17 & 18 & 2.06 & 6 \\
\hline Project resource \& quality management - Supply & 5 & 17 & 28 & 2.46 & 3 \\
\hline Inflation Rate - Price & 1 & 10 & 39 & 2.76 & 2 \\
\hline GDP - Price & 13 & 15 & 22 & 2.18 & 5 \\
\hline Foreign Labour in construction - Price & 29 & 13 & 8 & 1.58 & 7 \\
\hline
\end{tabular}

\subsection{Factors and Influence Level}

Population growth is common fact in developing country. Klang Valley as important business, industrial, and developing prime city had massive population increment as far as its citizen, urban migrant and foreign immigrant. This had definitely posing high housing demand. Respondents who perceived positive influence level in increasing demand on housing property also stated buy and resell process would influence rise of house price in Klang Valley with the influencing level. House dealer or house owner themselves would get known of market value of a house and set the price to its highest profit level in order to earn in term of investment, and usually subject to unequalvalence $50-180 \%$ mark up. Also another $10-40 \%$ mark up if dealing with house dealer, agent or middle person (Lee, 2009).

About $70 \%$ respondents in fraction $16 \%$ perceived highly influence and another 54\% somehow influence, are in opinion GDP growth influence significantly the rise of house price. Higher GDP translates into every going high. As GDP growth, house price would growth as the same path and this had bringing positive profit progressing to prime construction industries and other side industries. Hence, this creates a backpush force enhancing house price level to new high. Although economy growth projecting slower path, but the GDP growth is still there increase concurrently the average house price.

The market is not responsive on providing affordable house and affordable financial scheme. The supply of affordable house is less encouraged which existence of low cost house is quite limited in term of quantity respect to its demand at that time. These issue had currently overcomed in slow path with existence of PR1MA and My First House Scheme. However demand is projected to far high and not to be fulfilled in short manner, however some people may shifted to purchase a house not under any affordable scheme due to urgent need and uncertain supply.

Malaysia National House Buyers Association perceived housing under affordable house scheme might only open for those first time home buyer, and implementing sell-after-build policy. The General Scretary of the Association quoted the affordable housing demand under PR1MA scheme in Gelang Patah are six times higher than house supply. Proven the housing supply is insufficient for huge demand (Nanyang, 2013).

Different consideration criteria, affordable range and age are influencing the respondents stated different opinion. Most of the respondents with average age 30-34 years old are target their house price affordable range within RM200,001 to RM300,000 and more concern about the house apperance and public facilities provided. They have desire to earn for better life style and living environment. They are mostly at the smoother career path and financial assistance enable them affordable to buy their first house.

Other cost factor contributes to house price as the house may sell under different situation and into different market strategy. Commision, agent fee and mark up according to market value are much higher than transaction, legal and duty fee.

Table 3: Factors influencing the rise of house price with rates, number of respondents and average index

\begin{tabular}{|l|l|l|l|l|l|l|l|}
\hline $\begin{array}{l}\text { Rate } \\
\text { Pre-Factor }\end{array}$ & 1 & 2 & 3 & 4 & $\begin{array}{l}\text { Average } \\
\text { Index }\end{array}$ & Ranking \\
\hline 1 & Rising construction cost & 2 & 3 & 29 & 16 & 3.18 & 2 \\
\hline 2 & Unresponsive supply of affordable house & 14 & 4 & 24 & 8 & 2.52 & 7 \\
\hline 3 & Gross domestic product growth & 11 & 4 & 27 & 8 & 2.64 & 6 \\
\hline 4 & Increasing demand of residential property & 9 & 0 & 29 & 12 & 2.88 & 4 \\
\hline 5 & Transaction, legal and duty fee & 29 & 2 & 18 & 1 & 1.82 & 9 \\
\hline
\end{tabular}




\begin{tabular}{|l|l|l|l|l|l|l|l|}
\hline 6 & Developing trend and fluctuation in housing market & 4 & 1 & 14 & 31 & 3.44 & 1 \\
\hline 7 & Buy and resell process & 10 & 0 & 31 & 9 & 2.78 & 5 \\
\hline 8 & Population growth & 4 & 4 & 34 & 8 & 2.92 & 3 \\
\hline 9 & Upgraded house quality, house appearance, and public facilities & 29 & 1 & 16 & 4 & 1.90 & 8 \\
\hline
\end{tabular}

1-Not influence, 2- Less influence, 3- Somehow influence, 4- Highly influence

\subsubsection{Reliability Test}

This test is run by inserting all particular data into SPSS Statistics 17 software data entry. Alpha scale is used in the analysis which applied commonly in survey based researching work. The alpha is also known under Cronbach's. Research had stated an alpha scale stick within 0.7-0.8 indicating the entitled data reliable for further analysis and reporting. In preliminary factor and influence level, Cronbach Alpha is obtained 0.754 , hence the reliability of the data from respondents is proven.

\subsubsection{T-Tests \& Pearson Correlation Test}

$\mathrm{T}$-Tests are tests for statistical significance that used with scale data. T-tests can be used in several different types of statistical tests to test whether there are differences between two groups based on the mean value of that variable. For every group of variables, a research hypothesis is first stated. Research hypothesis in this test is the first factor is causing higher causality to the test issue as compared to second factor. Also, a null hypothesis is also necessary. Null hypothesis in this test is the first factor and second factor had no different level of causality to test issue.

Test hypothesis would be proven correct once if the T-Tests showing less than $0.10 \mathrm{sig}$. value. Or $\mathrm{t}$ value is bigger than $\mathrm{t}$ value obtained from $\mathrm{T}$-distribution table under designated degree of freedom $(\mathrm{df}=50-1=49)$ and confidence interval 0.10 .

T-test shows all the pre-factor are significant which is obeying the entire test hypothesis except for factor 2-factor 3 and factor 5 -factor 9 (refer Table 4). The correlation does not occur in these paired pre-factor. In further, there are nine paired factor significance should occurred proven through Pearson correlation test as shown in right hand side Table 4. By comparing these tests, there are statistical correlations between pre-factor 1 to pre-factor 9 and within each others. That means, increases or decreases in one variable do significantly relate to increases or decreases in factors and hence there are believed no causation imposed within the pre-factors although significances occurred.

Table 4: Paired factor with significant value less than 0.10 both t-test $\&$ Pearson correlation test

\begin{tabular}{|l|l||l|l|l|}
\hline T-Test & PEARSON Correlation Test \\
\hline Side A & $\begin{array}{l}\text { Significance } \\
(\text { sig. }<0.10)\end{array}$ & Side A & Side B & Significance (sig. < 0.10) \\
\hline \multirow{2}{*}{$\begin{array}{l}\text { All pre-factor paired with sig <0.10 except the } \\
\text { Factor 2 \& Factor 3, } \\
\text { and }\end{array}$} & Factor 1 & Factor 6 & 0.006 \\
\cline { 2 - 4 } Factor 5 \& Factor 9 & Factor 2 & Factor 3 & 0.025 \\
\cline { 2 - 4 } & Factor 2 & Factor 5 & 0.000 \\
\cline { 2 - 4 } & Factor 3 & Factor 8 & 0.001 \\
\cline { 2 - 4 } & Factor 3 & Factor 7 & 0.000 \\
\cline { 2 - 4 } & Factor 4 & Factor 5 & 0.019 \\
\cline { 2 - 4 } & Factor 4 & Factor 6 & 0.002 \\
\cline { 2 - 4 } & Factor 4 & Factor 8 & 0.065 \\
\cline { 2 - 4 } & Factor 5 & Factor 9 & 0.087 \\
\hline
\end{tabular}

\subsection{House Buyer Consideration Criteria}

From table 5, the criteria are marked the upper trend of concern level. Respondents would think financial convenience as most important criteria relating closely to buyer confidences to purchase a house as the average index 4.46 ranked top. Financial conveniences is commonly provide house buyer with more confidence to come over with more selection house type and price range. For example, increases in term of cash and payback flexibility while they purchase a house.
Affordability, ranked third, played around with house buyers' confidence by which they make a purchase during hike of house price and its payback does not suffering their normal life and breakdown their financial power. These three criteria are equivalently affecting house buyer nowadays.

Location, security and quality are varied into average index 4.00 to 4.20 . There are more in psychological phase where house buyer can only rate according to own expectation and 
observation whether the house worth to be invested. House buyer would consider location of housing property in certain with security concern at that area, which crime control and safety policy are all included. Ideal location is usually talking about house buyer or his/her households near to, easy to get to their active area, also in concern with, both environmental and physical quality of the house itself or the surrounding area. Besides, respondents also consider public facilities (3.98) and surrounding developments (3.90) of their ideal housing area. Public facilities especially are mainly related accessibility to transportation services, provision of public activity area, shops for daily products or household needs, and etc.
Appearance, expandability and resell value of housing property are contributing lower index. These explained most respondents foresee function of house by achieving only their basic needs as a place to live in, a shelter for family members, and a circumference compound for doing life without worrying of any judgment and attack. House appearance, expandability and resell value are mostly depends on owing a house for advance needs such as pleasurable and enjoyable pension life, value guarantee investment, and doubles or triples basis reselling price potential.

Table 5: Housing criteria with rate, average index and ranking

\begin{tabular}{|l|l|l|l|l|l|l|l|}
\hline \multicolumn{1}{|c|}{ Rate } & 1 & 2 & 3 & 4 & 5 & $\begin{array}{l}\text { Average } \\
\text { Index }\end{array}$ & Ranking \\
\hline Price & 1 & 0 & 10 & 5 & 34 & 4.42 & 2 \\
\hline Appearance & 2 & 2 & 19 & 13 & 14 & 3.70 & 9 \\
\hline Resell Value & 2 & 1 & 21 & 20 & 6 & 3.54 & 11 \\
\hline Location & 0 & 1 & 10 & 17 & 22 & 4.20 & 4 \\
\hline Surrounding Development & 0 & 1 & 14 & 24 & 11 & 3.90 & 8 \\
\hline Security & 0 & 1 & 9 & 21 & 19 & 4.16 & 5 \\
\hline Expandability & 0 & 3 & 19 & 22 & 6 & 3.62 & 10 \\
\hline Quality & 0 & 2 & 8 & 20 & 20 & 4.16 & 5 \\
\hline Affordability & 0 & 2 & 5 & 16 & 27 & 4.36 & 3 \\
\hline Public Facilities & 2 & 1 & 10 & 20 & 17 & 3.98 & 7 \\
\hline Financial Conveniences & 0 & 0 & 5 & 17 & 28 & 4.46 & 1 \\
\hline
\end{tabular}

1-Not related, 2- Very Unconcern, 3- Less concern, 4- Somehow Concern, 5- Very concern

\subsection{Cost of Construction}

Housing is depends on developing and construction activity. These also include fund placement, effective time, sufficient workforce, machinery, technology and thus all of these include cost effective concern. As public, it is assume that they have the knowledge in the rise of housing material, material economic, housing economic in the research area. This knowledge and informatin can easily get through the daily news, economic outlook and other information centres.

Most respondents have concerned land price and its cost to hire into construction activity. Fluatuation material pricing influencing directly the construction cost causing unpredictable house price in future days. According to Mr. Chang, developers nowadays intended to engage more profession in developable land, material sourcing for smoothening material supply and less intention to hire labour. This had been acknowledged by ranking above where land price and material sourcing stand the top point, beyond labour issue.

Semi skilled and general worker build up the low level labour hierarchy in Klang Valley, while labour market getting significant high supply and pro-saturated condition. In other word, labour and material are forming two poles of construction fund contributor, however there are not occupied any causility among each other. Then project period and labour are ranked third with the same 4.02 average index. Extra cost would involves if subject to these two which usually occurred once involving large scale of skilled labour, large time consuming with skills and inordinary technical procedure. For example: dealing with slope, unstable soil level, limited space, or avoiding common injures and accidents. Involvement of heavy machinery are common cost measure since modern construction would include more heavy machinery for transporting material and doing material handling work instead of using labour force. Same as labour, involvement of heavy machinery are common but important measure in conventional building system. Most people would perceived less concern onto heavy machinery cost measure which most of the time it is unavoidance. 
Table 6: Construction cost contributors with rate, average index and ranks

\begin{tabular}{|l|l|l|l|l|l|l|l|}
\hline Rate & 1 & 2 & 3 & 4 & 5 & $\begin{array}{l}\text { Average } \\
\text { Index }\end{array}$ & Rank \\
\hline Land Price & & 0 & 0 & 9 & 16 & 25 & 4.32 \\
\hline High Technology \& Heavy Machinery & 2 & 0 & 15 & 27 & 6 & 3.7 & 6 \\
\hline Material & 0 & 0 & 16 & 15 & 19 & 4.06 & 2 \\
\hline Project Period & 0 & 1 & 14 & 18 & 17 & 4.02 & 3 \\
\hline Build Difficulty & 1 & 1 & 15 & 18 & 15 & 3.9 & 5 \\
\hline Labour & 0 & 0 & 15 & 19 & 16 & 4.02 & 3 \\
\hline
\end{tabular}

1-Not related, 2- Very Unconcern, 3- Less concern, 4- Somehow Concern, 5- Very concern

\section{CONCLUSIONS}

According to the respond from the survey, it can be conclude that the main factors that influence the rise of house price are (i) Fluctuations in housing market, (ii) Rise in construction costs of housing, (iii) Population growth over housing, (iv) Increasing demand on housing, (v) Long term profit of housing, (vi) GDP growth, (vii) Declining in supply of new housing, (viii) Transfer fee and taxation of housing, and (ix) Housing quality, house appearance and public facilities.

Data collections from respondents are adopted into a tabulated format based on survey category and per each respondent. 2tailed paired configuration is used since the natural of this research are whether the causation occurred between the paired variable. Pearson correlation test and t-test are showing significances occurred within the factors variables. The influence level is adopting the average index as calculated in Table 3. Based on Table 3, overall index cumulating the entire single average index is determined as 2.67. 2.67 index is placed into 'AVERAGE' mean level as it drops into $1.50<$ mean index $\leq 2.75$. Hence, all the factors are occurring averagely with average influencing level to the research issue. Housing consideration criteria is more over discussing cost and engineering economical implication into the rise of house price in Klang Valley. Housing developers, construction operators, dealers, agents, and representatives are adopting the importance of consideration criteria to decide house selling price at their particulars.

In another fraction, construction cost is influencing severely the house price, as its adjustment would definitely rising magnitude into house price. Developer or other particulars would foresee the potential of housing unit to maximize their profit level. The chain of cost had again end to house buyer. The test had been run for several construction cost contributors as reviewed by researcher: Land, materials, project period, build difficulty, technology and heavy machinery involvement.

\section{ABBREVIATIONS}

CBRE: Cb Richard Ellis, Among The World's Premier, Full Service Real Estate Company

JPPH: Valuation and Property Service Department

PR1MA: Program Perumahan 1 Malaysia

OECD: Organization For Economic Co-Operation And Development

REHDA: Real Estate and Housing Developers' Association Malaysia

SPSS: Statistical Package for the Social Sciences

\section{REFERENCES}

[1] Agus, M. (1997). Urban development and housing policy in Malaysia. International Journal for Housing Science and its Application 21(2), 97-106.

[2] Ameera, P.M. K., Rosadah, M., \& PM Dr. Norhaya, K. (2012). An overview of housing affordability for first time home buyer in Malaysia. 3rd International Conference on Business and Economic Research Proceeding, (pp. 388-400). Bandung, Indonesia.

[3] Aziz, A. (2001). Bangladeshi migrant workers in Malaysia's construction sector. Asia Pacific population Journal 16(1) , 3-22.

[4] Badir, Y.F., Kadir, M.R.A., \& Ali, A.A.A. (1998). Theory of classification on Badir-Razali building system classification. Bulletin of Institution of Engineers, Malaysia .

[5] Bakar, A.S. (2002, January). Migrant labor in MalaysiaL impact and implications of the Asian financial crisis. Retrieved November 29, 2012, from http://www.eadn.org/Migrant\%2520Labour\%2520in\%2 520Malaysia\%2520Impact\%2520and\%2520Implication s\%2520of\%2520the.pdf

[6] Baker, T. (1994). Doing social Research Second Edition. New York: McGraw-Hill Inc.

[7] Bawa, C. A., \& Azriyati, W. (2010). Pragmatic housing policy in the quest for low income group housing delivery in malaysia. 
[8] CBRE. (2011). Property market overview. Kuala Lumpur.

[9] Chen, E. (2000). An overview of the Malaysian property market. UPM Workshop: Environment Friendly Township for Developing Countries. Serdang, Malaysia: UPM Press.

[10] Chong, J. H. (2012, September 28). Budget 2013 Government proposes higher property gains tax. Retrieved November 14, 2012, from The Edge Your Window to Malaysia : http://www.theedgemalaysia.com/businessnews/221594-budget-2013-government-proposeshigher-property-gains-tax.html

[11] Dan, A. (2010). Real house prices in OECD countries: the role of demand shocks and structutal and policy factors. Economics Department Working Paper 831 .

[12] Donald, L. H. (1989). Cause and consequence in public policy theory. Netherland: Kluwer Academic Publishers.

[13] Edmund, N. (2012, September 30). Lower house price when more affordable homes are build says SPNB.

[14] Francescato, G., Weidermann, S., \& Anderson, J. (1987). Residential satisfaction: its uses and limitations in housing research. Housing and neighbourhood: Theoretical and empirical contributions (pp. 43-57). Westport: Greenwood Press.

[15] Goh, J. (2012, June 11). Property prices increase at slower pace. Retrieved September 27, 2012, from The EDGE: http://www.theedgemalaysia.com/in-thefinancial-daily/215199-property-prices-increase-atslower-pace.html

[16] Hamzah, A. R., Lincoln, C. W., Low, S. F., \& Wang, C. (2012). Negative impact induced by foreign workers: evidence in Malaysia construction sector. Habitat Internatonal 36, 433-443.

[17] Hamzah, A. R., Wang, C., Lincoln, C. W., \& Khoo, Y. M. (2012). Defects in affordable housing projects in Klang Valley, Malaysia. Journal of Performance of Constructed Facilities .

[18] Haron, N.A., Salihuddin, H., Razali, M.A., \& Saleh, M.J. (2005). Building cost comparison between conventional and formwork system. Jurnal Taknologi 43 (B) , 1-11.

[19] Hwang, S., Park, M., Lee, H., \& Kim, W. (2010). Korean real estate market and mortgage lending policies: a quantitative approach. Contruction Research Congress 2010 (pp. 309-317). American Society of Civil Engineer.

[20] Ibrahim, M., Faizah, A., \& Norazriyati, W. (2012). Exploiting town planning factors in land development: Case stude of urban housing in Kuala Limpur, Malaysia. Journal of Facilities Management, 307-317.

[21] Ismail, E. (2001). Industrialized building system for housing in Malaysia. The Sixth Asia-Pacific Science and Technology Management Seminar. Tokyo.
[22] Johansson, A. (2010). Housing policies in OECD and candidate for Accession countries: Survey-based Data and Implications. OECD Economics Department Working Papers .

[23] John, M. Q. (1999). Real estates prices and economic cycles. Berkeley.

[24] Kassim, A. (2005). Cross-border movement of foreign workers in Malaysia: a comparative analysis . Master Builders Journal 3rd Quarter , 79-91.

[25] Khalfan, M., McDermott, P., Li, X., Arif, M., \& Kashyap, M. (2008). Developing innovative procurement strategies to integrate suppliers and manufacturers within construction industry. International Journal on Value Chain Management , 358-370.

[26] Lee, C. L. (2009). Hosuing price volatiliy and its determinants. International Journal of Housing Markets and Analysis 2(3) , 293-308.

[27] Lew, Y.L., Hassim, S., \& Kadir, M. (2003). Factors contributing to cost control problem problems in Malaysia industrialized building system construction. International Conference on Industrial Building System. Kuala Lumpur.

[28] Lou, E., \& Kamar, K. (2012). Industrialized building system: strategic outlook for manufactured construction in Malaysia. UK.

[29] Mamta, B. (2012, June 20). The three most important factors driving home prices. Retrieved December 1, 2012, from Business Insider: Money Game: http://www.businessinsider.com/beata-caranci-td-3most-important-factors-driving-home-prices-2012$6 ?$ op $=1$

[30] Michele, D. (2012). How to set your selling price. Retrieved December 02, 2012, from Realtor.com: http://www.realtor.com/home-finance/realestate/sellers/setting-price-for-sellinghome. aspx? ?source $=$ web

[31] Mohammad, A., Mansor, I., \& Yong, R. R. (2010). Assessment of residential satisfaction in newly designed public low-cost housing in Kuala Lumpur, Malaysia. Habitat International $34,18-27$.

[32] Mohd, Y. H., Rahana, A. R., Fairuz, N. M., Lyndon, N., \& Nadia, N. I. (2012). Housing bubbles assessment 2005-2010: Experiences in Klang Valley, Malaysia. Advances in Natural and Applied Sciences, 6(1), 33-41.

[33] Nanyang (2013, March). House Buyers' Association: Affordable house should only open for first time home buyer. Retrieved May 20, 2013, from http://www.nanyang.com/node/517869?tid=460

[34] Narayanan, S., \& Lai, Y. (2005). The causes and consequences of immigrant labour in the construction sector in Malaysia. International Migration 43(5), 3157. 
[35] Nurizan, Y., \& Hashim, A. (2001). Perumahan dan Kdiaman. UPM Malaysia.

[36] Oh, L. (2000). Housing satisfaction of middle income households in Bandar Baru Bangi, Selangor. Dissertation .

[37] Ramli, M. (2003). The need for systematic project management in construction industry. Malaysia Macroworks .

[38] Razali, M. A., Kadir, M.A., Lee, W., Saleh, M. J., Sapuan, M. S., \& Ali, A. A. (2006). Construction performance comparison between conventional and industrialized building systems in Malaysia. Structural survey 24(5), 412-424.

[39] Salleh, A., \& Shiadri. (2008). Causes of poor participation of local workers in Malaysia construction industry and strategies for improvement. Skudai: UTM, Faculty of Civil Engineering.

[40] Sambasivan, M., \& Yau, W. (2007). Causes and effects of delays in Malaysian construction industry. International Journal of Project Management 25(5), 517-526.

[41] Stephen, M. (2010). Urban regulation, the "new economy," and housing prices. Housing Debate 13(2), 323-349.

[42] Talhar, C. W., \& Wong. (2012, June 28). House Price in Malaysia.

[43] Tan, Y. K. (2005). An hedonic model for house price in Malaysia.

[44] Terence, W. C. (2012). Hot property. Kuala Lumpur: CIMB, Malaysia.

[45] Terence, W. C. (2012). Property Devt \& Invt. Kuala Lumpur: CIMB.

[46] Thanoon, W., Razali, M. A., Saleh, M. J., Sapuan, M. S., \& Lee, W. P. (2003). The essential characteristic of industrialized building system. International Conference on Industrialized Building Systems, (pp. 283-292). Kuala Lumpur.

[47] Thean, L. C. (2012, August 21). Demand for house and real estate in Klang Valley continues despite high prices. Retrieved November 7, 2012, from biz.thestar.com.my/news/story.asp?file=/2012/8/21/busi ness $/ 11865411 \&$ sec $=$ business

[48] Varady, D., \& Carozza, M. (2000). Towards a better way to measure customer satisfaction levels in public housing: a report from Cincinnati. Housing Studies 15(6), 797-825.

[49] Zainal, A. H. (2010). House Price and Affordability in Housing in Malaysia. Akademika 78 , 37-46. 